\title{
PENERAPAN MODEL LITERASI MEDIA SOSIAL INSTAGRAM PADA PETUGAS PENGOLAH DATA DAN SISTEM INFORMASI (PEDASI) KECAMATAN CINAMBO \\ (Studi Deskriptif Penerapan Model Literasi Media Instagram @ kecamatan.cinambo Sebagai Media Informasi Kecamatan Cinambo)
}

\author{
Rachmawati Windyaningrum ${ }^{1}$, Shinta Hartini Putri ${ }^{2}$, Indah Sari ${ }^{3}$ \\ Fakultas Komunikasi dan Desain ,Universitas Informatika dan Bisnis Indonesia \\ Email: rachma.ningrum@unibi.ac.id ${ }^{1}$ shintahartiniputri@unibi.ac.id² indahsari@unibi.ac.id ${ }^{3}$
}

\begin{abstract}
Abstrak
Sejak tahun 2013 Pemerintah Kota Bandung mulai mencanangkan Bandung Smart City dengan mendayagunakan perkembangan teknologi komunikasi melalui aktivasi media sosial. Aktivasi ini merupakan instruksi Wali Kota Bandung bahwa seluruh SKPD (Satuan Kerja Pemerintah Daerah). Pada tingkat kecamatan aktivasi media sosial dilakukan dengan cara membuat akun twitter, Facebook, dan Instagram. Akun media sosial tersebut digunakan sebagai media pengontrol kinerja aparat pemerintah tingkat kecamatan, karena aktifitas media sosial akan menjadi rapor camat atau lurah oleh warga. Instagram Kecamatan Cinambo @kecamatan.cinambo yang tercatat aktif dengan jumlah posting sebanyak 1055, pengikut 1047 hingga agustus 2018. Penelitian ini bertujuan untuk mengeksplanasi penerapan literasi media sosial oleh Petugas Pengolahan Data dan Informasi dalam menggunakan Instagram. Dalam mencapai tujuan tersebut penelitian ini menggunakan metode penelitian kualitatif deskriptif, dengan teknik pengumpulan data primer melalui observasi dan wawancara, sedangkan data sekunder menggunakan studi literatur buku, jurnal, dan sumber internet. Analisa data yang digunakan dengan model Miles dan Huberman dan triangulasi untuk teknik keabsahan data. Penerapan model literasi media sosial Instagram menunjukkan bahwa PEDASI Kecamatan Cinambo sudah memiliki kemampuan akses, keahlian teknis, pemahaman kritis dalam manajemen informasi, dan keahlian produksi konten informasi kegiatan Kecamatan Cinambo.
\end{abstract}

Kata Kunci : Literasi, Media Sosial, Kecamatan, Instagram, Literasi Digital

\begin{abstract}
Since 2013, the Bandung City Government has launched the Bandung Smart City by utilizing the development of communication technology through the activation of social media. This activation is an instruction from the Mayor of Bandung that all SKPD (Regional Government Work Units). At the subdistrict level social media activation is done by creating Twitter, Facebook and Instagram accounts. The social media account is used as a media to control the performance of the sub-district level government apparatus, because social media activities will become a report card for the subdistrict head or lurah by the residents. Instagram Cinambo Subdistrict @ kecamatan.cinambo which is active with a total of 1055 posts, 1047 followers until August 2018. This study aims to explore the application of social media literacy by Data and Information Processing Officers (PEDASI) in using Instagram. In achieving these objectives this research uses descriptive qualitative research methods, with primary data collection techniques through observation, interviews and focus group discussions (FGD), while secondary data uses literature studies of books, journals, and internet sources. Data analysis is used with the Miles and Huberman models and triangulation for data validity techniques. The application of Instagram social media literacy model shows that PEDASI Cinambo District already has access capabilities, technical expertise, skills in information management, and expertise in producing information content for Cinambo District activities.
\end{abstract}




\section{Keywords: Literacy, Social Media, Districts, Instagram, Digital Literacy}

\section{PENDAHULUAN}

\subsection{Latar Belakang}

Kecamatan Cinambo merupakan salah satu kecamatan berprestasi di Kota Bandung, semenjak tahun 2016 kecamatan ini dinobatkan sebagai juara pertama kecamatan berprestasi tingkat kota. Prestasi Kecamatan Cinambo ini memang tidak bertahan lama, namun Kecamatan Cinambo selalu menjadi masuk dalam jajaran sepuluh kecamatan terbaik di Kota Bandung. Kecamatan Cinambo setiap tahunnya memiliki program tahunan untuk mewujudkan pengembangan visi Kota Bandung sendiri. Pada tahun 2016 memiliki program Cinambo Wisata, tahun 2017 program Cinambo Sejahtera, tahun 2018 program Cinambo Juara, dan di tahun 2019 program Cinambo Literasi. Program Cinambo Literasi ini menjadi program unggulan Kecamatan Cinambo sebagai kecamatan percontohan atas kemampuan memahami khususnya di bidang minat baca dan pengelolaan informasi melalui media sosial. Literasi minat baca ditandai dengan adanya program-program mingguan kecamatan yang menyediakan fasilitas perpustakaan di setiap kelurahan maupun kegiatan membaca bersama dengan warga disetiap akhir pekan. Sementara, literasi pengelolaan informasi melalui media sosial lebih ditujukan kepada para Aparatur Sipil Negara tingkat kecamatan.

Pengelolaan informasi melalui media sosial merupakan bentuk pengelolaan informasi mengenai informasi kecamatan yang mendukung keterbukaan informasi publik. Hal ini sejalan dengan amanat UU Nomor 14 Tahun 2008 tentang Keterbukaan Informasi Publik, Peraturan Komisi Informasi Nomor 1 Tahun 2010 tentang Standar Layanan Informasi Publik, dan Peraturan walikota Bandung Nomor 1352 Tahun 2014 tentang Pedoman Pengelolaan Informasi dan Dokumentasi di Lingkungan Pemerintah Kota Bandung. Landasan hukum tersebutlah yang menjadikan terbentuknya Pejabat Pengelola Informasi dan Dokumentasi (PPID). PPID yang berada di tingkat kota memiliki peran dan fungsi sebagai pengelola dan penyampai dokumen yang dimiliki oleh badan publik.

${ }^{1}$ https://ppid.kominfo.go.id/standar-layanan-ip/, diakses pada tanggal 12 Agustus 2019 pukul 11.20 keberadaan PPID maka masyarakat yang akan menyampaikan permohonan informasi lebih mudah dan tidak berbelit karena dilayani lewat satu pintu. PPID adalah pejabat yang bertanggung jawab di bidang penyimpanan, pendokumentasian, penyediaan, dan/atau pelayanan informasi di badan publik $^{1}$. PPID tidak hanya di tingkat kota, namun juga di tingkat kecamatan harus diterapkan melalui peran Petugas Pengolah Data dan Sistem Informasi (PEDASI). PEDASI di Kecamatan Cinambo memiliki peran sebagai petugas sistem informasi yang mengelola data terkait Sistem Informasi Pemerintah (SIP) dan pengelolaan media yang berbasis internet, seperti website, e-mail, dan akun media sosial.

Peran PEDASI sangat penting sebagai penyedia informasi dan sosialisasi kegiatan Kecamatan Cinambo. Selain itu, PEDASI memiliki peran untuk mendukung peningkatan kinerja kecamatan melalui aktivitas pelaporan kegiatan kecamatan kepada pemerintah kota. Pelaporan kegiatan kecamatan tersebut dilakukan melalui sistem yang sudah tersedia, serta didukung oleh aktifasi website maupun media sosial. Hal ini dikarenakan website maupun media sosial dapat diakses oleh seluruh warga Kecamatan Cinambo, sehingga kegiatan kecamatan tidak hanya bersifat pelaporan kinerja tetapi juga sebagai informasi kepada warga Cinambo. Aktivitas tersebut sejalan dengan instruksi Wali Kota Bandung melalui Surat Edaran tahun 2016 tentang Pembuatan Serta Pemutahiran Web dan Akun Media Sosial (Twitter, Facebook, dan Instagram) Di Lingkungan Pemerintahan Kota Bandung. Berdasarkan surat edaran ini, Kecamatan Cinambo mengaktifkan website yang beralamatkan https://kecamatancinambo.go.id dan akun media sosial yakni, Facebook Kecamatan Cinambo https://www.facebook.com/Kecamatan-CinamboBersatu-777774282234543/, Twitter Kecamatan Cinambo https://twitter.com/cinambokec_?lang=en dan Instagram Kecamatan Cinambo @ kecamatan.cinambo. 
Website Kecamatan Cinambo terdapat profil, kegiatan, berita, bahkan pengumuman Kartu Tanda Penduduk (KTP) ataupun Kartu Keluarga (KK) yang telah selesai dibuat. Website ini terintegrasi dengan akun media sosial yang dimiliki Kecamatan Cinambo. Sejalan dengan trend di masyarakat akun media sosial Kecamatan Cinambo yang dikelola PEDASI setiap harinya adalah Instagram @kecamatan.cinambo. Akun Instagram tersebut dipilih karena secara penggunaan dan fungsi yang membantu proses kerja PEDASI dalam pelaporan kegiatan kecamatan maupun publikasi informasi kepada warga Cinambo secara maya. Instagram @kecamatan.cinambo tercatat aktif dengan jumlah posting sebanyak 1055, pengikut 1047 hingga agustus 2018. Kini di tahun 2019, Instagram Kecamatan Cinambo memiliki pengikut sebanyak 1.257 dengan jumlah posting sebanyak 1.543. Hal tersebut menjadi wujud adanya literasi media baru di kalangan aparatur pemerintah daerah dalam mengelola informasi melalui media sosial. Literasi media baru menurut Paul Gilster (Martin, 2009) adalah kemampuan untuk memahami dan menggunakan informasi dalam berbagai format dari berbagai sumber yang disajikan melalui komputer.

Pengelolaan informasi tersebut tidak terlepas dari tugas utama PEDASI yang harus aktif melakukan peliputan giat Camat Cinambo. Hasil peliputan tersebut selanjutnya dijadikan bahan konten Instagram @ kecamatan.cinambo. Secara teknis PEDASI diharuskan memiliki kemampuan untuk menggunakan aplikasi akun media sosial terutama Instagram @ kecamatan.cinambo, namun kemampuan tersebut harus didukung pula dengan pemahaman kritis dan cara memproduksi konten yang layak disampaikan bagi warga Kecamatan Cinambo maupun Pemerintah Kota Bandung. Hal ini dikarenakan dari hasil publikasi yang terlihat pada Instagram @kecamatan.cinambo hanya berupa foto kegiatan camat (giat camat), MUSPIKA kecamatan, TP. PKK, dan program kerja kecamatan. Berdasarkan penjelasan tersebut, PEDASI memiliki tugas penting sebagai jembatan utama antara warga Kecamatan Cinambo dengan kecamatan serta kepada Pemerintah Kota Bandung sebagai petugas yang senantiasi melaporkan kinerja baik Camat maupun kecamatan. Oleh karena itu, penelitian ini akan menjelaskan literasi media sosial yang terjadi di Kecamatan Cinambo melalui aktivitas PEDASI dalam mengelola Instagram @kecamatan.cinambo sebagai media informasi kecamatan. Selain itu, penelitian ini akan menghasilkan model literasi media sosial yang diterapkan pada Kecamatan Cinambo.

\subsection{Fokus dan Pertanyaan Penelitian}

Fokus dalam penelitian ini adalah Penerapan Model Literasi Media Sosial Instagram Pada Petugas Pengolah Data Dan Sistem Informasi (PEDASI) Kecamatan Cinambo?. Sedangkan pertanyaan penelitian yang digunakan untuk mengungkap fokus penelitian adalah,

1. Bagaimana penerapan aspek keahlian teknis media sosial pada PEDASI Kecamatan Cinambo?

2. Bagaimana penerapan aspek pemahaman kritis pada PEDASI Kecamatan Cinambo?

3. Bagaimana penerapan aspek produksi konten pada PEDASI Kecamatan Cinambo?

4. Bagaimana model penerapan literasi media sosial Instagram pada PEDASI Kecamatan Cinambo?

\subsection{Tujuan Penelitian}

Adapun tujuan dari penelitian ini adalah sebagai berikut,

1. Untuk mengeksplanasikan penerapan aspek keahlian teknis media sosial pada PEDASI Kecamatan Cinambo.

2. Untuk mengeksplanasikan penerapan aspek pemahaman kritis pada PEDASI Kecamatan Cinambo.

3. Untuk mengeksplanasikan penerapan aspek produksi konten pada PEDASI Kecamatan Cinambo.

4. Untuk menggambarkan model penerapan literasi media sosial Instagram pada PEDASI Kecamatan Cinambo.

\subsection{Manfaat Penelitian}

Adapun manfaat penelitian ini sebagai bahan masukan dan evaluasi terkait penerapan model literasi media sosial Instagram yang dimiliki PEDASI, meliputi kemampuan mengakses, keahlian teknis dalam penggunaan media sosial, mengembangkan pemikiran kritis dan manajemen informasi, serta memproduksi konten informasi bagi warga Kecamatan Cinambo dan Pemerintah 
Kota Bandung. Selain itu, penelitian ini diharapkan sebagai referensi mengenai literasi media sosial yang dapat mendukung konsep Bandung Smart City Pemerintah Kota Bandung.

\section{TINJAUAN PUSTAKA}

\subsection{Media Baru}

Seiring berkembangnya teknologi informasi di zaman milineal saat ini memunculkan media baru yang sangat membantu dan berperan penting untuk kehidupan masyarakat. Di mana media baru dapat membantu perekonomian masyarakat dengan cara berbisnis online, akan tetapi kini media baru ramai diperbincangkan sebagai alat untuk promosi, berkampanye, bahkan mensosialisasikan kegiatan kemasyarakatan lingkungan masyarakat. Media baru menurut Carey (McQuail, 2011) adalah media yang berbasis internet dengan menggunakan komputer dan telepon genggam canggih. Dua kekuatan utama perubahan awalnya adalah komunikasi satelit dan pemanfaatan komputer. Kunci untuk kekuatan komputer yang besar sebagai sebuah mesin komunikasi terletak pada proses digitalisasi yang memungkinkan segala bentuk informasi dibawa dengan efisien dan saling berbaur.

Media baru disebut juga new media digital. Media digital adalah media yang kontennya berbentuk gabungan data, teks, suara dan berbagai jenis gambar yang disimpan dalam format digital dan disebarluaskan melalui jaringan berbasis kabel optic broadband, satelit dan system gelombang mikro (Flew, 2008). Media baru merupakan media komunikasi yang mempermudah khalayak untuk mengakses segala informasi dengan cepat dan dapat diakses kapanpun dimanapun tanpa ada batas waktu yang ditentukan, kemudian media baru juga mempermudah khalayak untuk bersosialisasi maupun berkomunikasi dengan orang-orang baru.

\subsection{Literasi Media Baru}

Literasi media baru menjadi topik yang menarik, mengingat konsep literasi tersebut berangkat dari perkembangan literasi media secara konvensional. Literasi media baru menjadi bagian

\footnotetext{
2 (Media Networking Awarness. National Broadband Plan Connecting Maerican Section 9.3, Digital Britain
}

dari konvergensi media di era baru yakni era digital. Seperti menurut Chen, dkk (2011) literasi media baru lebih banyak diartikan sebagai kombinasi keterampilan informasi, keterampilan komputer konvensional dan keterampilan komunikasi (atau literasi majemuk). Sependapat dengan Chen, dkk, menurut Putra $(2017,275)$ menjelaskan bahwa literasi media baru dipahami sebagai konvergensi semua literasi yang berkembang pada abad terakhir yang mencaakup literasi klasik, literasi audiovisual, literasi digital, dan literasi informasi.

Berdasarkan penjelasan tersebut dapat disimpulkan terdapat kesamaan konsep antara literasi media baru dengan literasi digital. Menurut Martin, dkk (2008) menjelaskan literasi digital lebih sekedar mengetahui cara menggunakan komputer, melainkan bagaimana orang membuat, memahami dan berbagi makna dalam konteks digital. Dengan demikian, literasi digital menggabungkan berbagai keterampilan yang saling terkait yang secara tradisional jatuh di bawah literasi seperti komputer atau informasi dan teknologi komunikasi, literasi teknologi, literasi informasi, literasi media, literasi visual, literasi komunikasi, literasi moral dan sosial. Literasi digital lebih dikenal lagi didefinisikan sebagai, keterampilan dan pengetahuan yang diperlukan untuk menggunakan berbagai perangkat lunak aplikasi media digital, perangkat keras seperti komputer, telepon selular, dan teknologi internet; kemampuan untuk secara kritis memahami konten media digital dan aplikasinya; dan pengetahuan dan kapasitas untuk menciptakan isi media dengan teknologi digital ${ }^{2}$ Maka, dalam definisi tersebut terkandung tiga kata kerja yang merupakan karakteristik dari literasi digital, yaitu: use - understand - create. Artinya, literasi media mencakup kemampuan untuk menggunakan, memahami, dan memproduksi media digital. Penjelasan lebih jauh mengenai ketika komptensi tersebut adalah:

1. Use (Menggunakan), merupakan keahlian teknis yang dibutuhkan untuk terlibat dengan komputer dan internet. Keahlian ini membentuk dasar untuk pengembangan literasi digital yang lebih dalam.

Media Literacy Working Group Section 3.16, dan Australia's Digital Economy: Future Directions., 2011) 
Keterampilan teknis yang penting meliputi kemampuan untuk menggunakan program komputer seperti pengolah kata, web browser, e-mail, dan alat komunikasi lainnya. Untuk mengembangkan keterampilan ini, warga harus memiliki akses dan dapat memanfaatkan peralatan dan sumber daya dengan nyaman seperti layanan broadband, komputer, perangkat lunak, mesin pencarian Internet, dan database online.

2. Understand (Mengerti), adalah kemampuan untuk memahami, mengontekstualisasikan, dan mengevaluasi media digital secara kritis. Individu harus menyadari pentingnya melakukan evaluasi secara kritis dalam memahami bagaimana konten dan aplikasi media digital dapat mencerminkan, membentuk, meningkatkan atau memanipulasi persepsi kita, keyakinan kita, dan perasaan kita tentang dunia di sekitar kita. Sebuah pemahaman kritis tentang media digital memungkinkan individu untuk menuai keuntungan dan mengurangi resiko, serta berpartisipasi penuh dalam masyarakat digital. Keterampilan ini mencakup juga pengembangan keterampilan manajemen informasi dan penghargaan terhadap hak dan tanggung jawab terhadap kekayaan intelektual. Individu perlu tahu bagaimana menemukan, mengevaluasi, dan menggunakan informasi secara efektif untuk berkomunikasi, berkolaborasi dan memecahkan masalah dalam kehidupan pribadi dan profesional.

3. Create (Memproduksi), adalah kemampuan untuk membuat konten dan berkomunikasi secara efektif menggunakan berbagai alat media digital. Produksi konten dengan menggunakan media digital tidak sekedar kemampuan untuk menggunakan pengolah kata atau menulis email: namun termasuk di dalamnya kemampuan berkomunikasi dalam berbagai konteks khalayak; untuk membuat konten dan berkomunikasi dengan menggunakan berbagai format seperti gambar, video, dan suara; dan untuk secara efektif dan bertanggungjawab memanfaatkan fasilitas "Web 2.0 usergenerated content" seperti blog dan forum diskusi, berbagai video dan foto, game sosial, dan bentuk lain dari media sosial. Kemampuan untuk membuat dengan media digital memastikan bahwa seseorang tidak hanya konsumen pasif tetapi secara aktif berkontribusi dalam masyarakat digital ${ }^{3}$.

\subsection{Media Sosial}

Media sosial dapat diartikan sebagai bentuk interaksi manusia melalui jejaring sosial di dunia maya. Seperti yang dikutip Sulianta $(2015,5)$ menurut (Ahlqvist, dkk, 2008) media sosial merupakan interaksi sosial antara manusia dalam memproduksi, berbagai dan bertukar informasi, hal ini mencakup gagasan dan berbagai konten dalam komunitas virtual. Media sosial juga dapat diartikan sebagai kelompok dari apikasi berbasiskan internet yang dibangun atas dasar ideologi dan teknologi web versi 2.0 yang memungkinkan terciptanya website yang interaktif (Kaplan dan Haenlein, 2010 dalam Sulianta, 2015).

Adapun karakteristik yang dijumpai pada medisa sosial modern (Sulianta, 2015):

1. Transparansi: keterbukaan informasi karena konten media sosial ditujukan untuk konsumsi publik atau sekelompok orang.

2. Dialog dan komunikasi: terjalin suatu hubungan dan komunikasi interaktif dengan ragam figure, misalnya antara "brand bisnis" dengan para "fans"nya.

3. Jejaring relasi: hubungan antara pengguna layaknya jarring-jaring yang terhubung satu sama lain dan makin kompleks seraya mereka menjalin komunikasi dan terus membangun pertemanan. Komunitas jejaring sosial memiliki peranan kuat yang akan memengaruhi audiensinya (influencer).

4. Multi opini: setiap orang dengan mudahnya beragumen dan mengutarakan pendapatnya.

5. Multi form: informasi disajikan delam ragam konten dan ragam channel,

${ }^{3} \mathrm{Ibid}^{2}$ 
wujudnya dapat berupa: social media press release, video news release, web portal, dan elemen lainnya.

6. Kekuatan promosi online: media sosial dapat dipandang sebagai tool yan memunculkan peluang-peluang yang tidak dengan sendirinya terbentuk begitu saja, peluang-peluang ini harus dimanfaatkan guna mewujudkan visi misi organisasi.

\subsection{Instagram}

Instagram adalah sebuah aplikasi dari Smartphone yang khusus untuk media sosial yang merupakan salah satu dari media digital yang mempunyai fungsi hampir sama dengan twitter, namun perbedaannya terletak pada pengambilan foto dalam bentuk atau tempat untuk berbagi informasi terhadap penggunaanya. Instagram juga dapat memberikan inspirasi bagi penggunanya dan dapat meningkatkan kreatifitas, karena instagram mempunyai fitur yang dapat membuat foto menjadi lebih indah, lebih artistik dan menjadi bagu (Atmoko Dwi, 2012).

Menurut ahli Atmoko (2012) instagram merupakan salah satu fitur yang dimiliki oleh telepon pintar. Instagram juga merupakan aplikasi yang digunakan untuk menjepret, mengelola, mengedit, memberi efek filter dan membagikan foto ataupun video tersebut kesemua orang. Lebih jelas lagi, "Instagram disukai karena kemudahan dan kecepatannya dalam berbagi foto ditambah beberapa filter bergaya retro yang menarik. Instagram memberikan cara baru berkomunikasi di jejaring sosial media melalui foto" (Atmoko, 2012).

Instagram memiliki lima menu utama yang semuanya terletak dibagian bawah (Atmoko, 2012) yaitu sebagai berikut:

\section{Home}

Page home page adalah halaman utama yang menampilkan (timeline) foto-foto terbaru dari sesama pengguna yang telah diikuti. Cara melihat foto yaitu hanya dengan menggeser layar dari bawah ke atas seperti saat scroll mouse di komputer. Kurang lebih 30 foto terbaru dimuat saat pengguna mengakses aplikasi, Instagram hanya membatasi fotofoto terbaru.

2. Comments

Sebagai layanan jejaring sosial Instagram menyediakan fitur komentar. Fotofoto yang ada di Instagram dapat dikomentar di kolom komentar. Caranya tekan ikon bertanda balon komentar di bawah foto, kemudian ditulis kesan-kesan mengenai foto pada kotak yang disediakan setelah itu tekan tombol send.

3. Explore

Explore merupakan tampilan dari foto-foto populer yang paling banyak disukai para pengguna Instagram. Instagram menggunakan algoritma rahasia untuk menentukan foto mana yang dimasukkan ke dalam explore feed.

4. Profil

Profil pengguna dapat mengetahui secara detail mengenai informasi pengguna, baik itu dari pengguna maupun sesama pengguna yang lainnya. Halaman profil bisa diakses melalui ikon kartu nama di menu utama bagian paling kanan. Fitur ini menampilkan jumlah foto yang telah diunduh, jumlah follower dan jumlah following.

5. News Feed

New feed merupakn Fitur yang menampilkan notifikasi terhadap berbagai aktivitas yang dilakukan oleh pengguna Instagram. News feed memiliki dua jenis tab yaitu "Following" dan "News". Tab "following" menampilkan aktivitas terbaru pada user yang telah pengguna follow, maka tab "news" menampilkan notifikasi terbaru terhadap aktivitas para pengguna Instagram terhadap foto pengguna, memberikan komentar atau follow maka pemberitahuan tersebut akan muncul di tab ini.

\section{METODE PENELITIAN}

Penelitian ini menggunakan metodologi penelitian kualitatif dengan jenis deskriptif. Penelitian deskriptif dilakukan untuk melihat kondisi literasi media sosial Instagram @ kecamatan.cinambo yang dikelola oleh PEDASI. Metode deskriptif digunakan sebagai desain penelitian yang menitikberatkan observasi alamiah dan suasana alamiah (natural setting), pada metode ini peneliti bertindak sebagai pengamat yang terjun ke lapangan. Untuk mengumpulkan data penelitian, peneliti menggunakan teknik pengumpulan data yang bersumber dari data primer dan sekunder. Data primer dalam penelitian ini terdiri dari Observasi 
non partisipan pada aktivitas media sosial Instagram @ kecamatan.cinambo, keadaan Kecamatan Cinambo, dan kegiatan kecamatan yang akan dipublikasi pada Instagram @ kecamatan.cinambo. Wawancara yang dilakukan menggunakan indepth interview kepada Camat Cinambo, PEDASI @ kecamatan.cinambo, dan Dinas Komunikasi dan Informasi Kota Bandung. Untuk data sekunder peneliti menggunakan studi literatur buku, jurnal, dan sumber internet tentang literasi media baru dan media sosial sebagai media informasi.

Penentuan informan dalam penelitian ini menggunakan teknik purposive sampling. Penelitian ini menggunakan teknik analisa data dengan model Miles dan Huberman. Model Miles dan Huberman merupakan teknik analisa data melalui beberapa tahapan yakni, pengumpulan data (data collection), reduksi data (data reduction), penyajian data (data display), dan penarikan kesimpulan (conclutions). Untuk mengetahui keabshan data dalam penelitian ini menggunakan teknik triangulasi waktu. Triangulasi waktu dilakukan dengan cara melakukan pengecekan dengan wawancara, observasi, atau teknik lain dalam waktu atau situasi yang berbeda (Sugiyono 2007). Peneliti melakukan pengecekan kembali dengan membandingkan data yang didapat dari hasil wawancara berbagai informan dengan hasil observasi di lapangan dan observasi berdasarkan data sekunder diwaktu yang berbeda.

\section{HASIL DAN PEMBAHASAN}

\subsection{Penerapan Aspek Keahlian Teknis Media Sosial Pada PEDASI Kecamatan Cinambo}

Kecamatan Cinambo sebagai kecamatan yang melakukan pengolahan data dan informasi melalui aktifitas media sosial tidak terlepas dari peran PEDASI. Peran PEDASI ini sesuai adanya kebijakan terkait PPID di lingkungan Pemerintah Kota, Satuan Kerja Pemerintah Daerah (SKPD), hingga wilayah yakni kecamatan. PPID Kecamatan Cinambo dikelola oleh PEDASI yang meliputi website kecamatan dan akun media sosial. PEDASI yang dipilih merupakan karyawan Aparatur Sipil Negara (ASN) berada di bawah Kepala Seksi Umum Kepegawaian Pengolahan Data dan

\footnotetext{
${ }^{4}$ Wawancara Informan Camat Cinambo, Juni 2019, Kecamatan Cinambo, Kota Bandung
}

Informasi (Kasi UMPEG Data dan Informasi). PEDASI ini pun tidak bekerja sendiri, namun dibantu oleh para karyawan Non-ASN yang memiliki dasar tentang sistem informasi atau informasi teknologi (IT). Pemilihan Non-ASN sebagai bagian dari staf IT diperlukan untuk mendukung pekerjaan PEDASI terkait pengolahan data informasi serta publikasi informasi baik secara konvensional maupun digital. Hal ini dijelaskan oleh Camat Cinambo bahwa, “"“jadi kita punya tim atau teman-teman yang setiap kecamatan punya tim IT namanya. Kita sengaja hired ya atau dikontrak oleh kita dan semua kecamatan juga sama"4. Tim IT atau PEDASI merupakan orang yang memiliki keahlian dalam mengakses media sosial dan mendistribusikan konten.

Baik PEDASI maupun staf IT Kecamatan Cinambo memiliki tugas rutin yang harus dilakukan mengenai pembuatan dan pendistribusian konten informasi kegiatan kecamatan melalui aplikasi Instagram @kecamatan.cinambo. Selain itu, PEDASI juga dituntut untuk dapat mengolah data kecamatan yang akan dilaporkan melalui aplikasi SIP (aplikasi tersendiri yang dimiliki Pemerintah Kota Bandung) sebagai bentuk pelaporan kinerja kecamatan. Dalam pembuatan dan pendistribusian konten di Instagram, PEDASI beserta staf IT harus mampu membuat konten dalam bentuk visualiasi gambar, tulisan maupun video yang memuat informasi kegiatan Kecamatan Cinambo. Berdasarkan hal tersebut, diakui PEDASI dan staf IT mereka harus memiliki keahlian dasar menjalankan perangkat komputer, laptop, dan smartphone yang terhubung dengan jaringan internet. Selain keahlian menguasai perangkat, PEDASI dan staf IT wajib memiliki keahlian teknis dalam mengunakan aplikasi media sosial, e-mail, website, dan software yang mendukung pembuatan konten informasi kegiatan informasi kecamatan. Seperti yang diungkapkan oleh staf Seksi Keterbukaan Informasi Publik DISKOMINFO Kota Bandung,

"Jadi kita bikin surat edaran pada saat itu surat edaran pa wali yah untuk mengadakan apa bukan mengadakan membuat medsos 
Twitter, IG, dan FB waktu itu. Nah untuk penetapan admin" nya itu sendiri itu di wewenangkan kepada kepala SKPD nya masing". Misalnya begitu surat edaran nyampe ke kecamatan Cinambo otomatis harus ada SK yang dikeluarkan siapa adminnya nah camat yang wewenang nya. Siapa yang disini istilahnya bisa IT misalnya dilihat dari seksi mana, misalnya si anu ini SK nya. Dibikinkan SK nya dilaporkan lah nanti ke diskominfo siapa yang jadi adminnya"5

Keahlian teknis dalam literasi media sosial adalah keahlian teknis penggunaan media sosial meliputi kemampuan mengoperasikan fitur-fiitur yang terdapat pada media sosial. PEDASI dituntut harus mampu membuat akun Instagram dengan terlebih dahulu mendaftarkan diri melalui e-mail dengan alamat cinambo.kecamatan@ yahoo.com. $E$ mail ini menjadi dasar untuk PEDASI mengaktifkan akun Instagram. Setelah itu, PEDASI memulai aktifasi Instagram dengan membuat alamat @ kecamatan.cinambo, memberikan biodata, dan memasang foto profil untuk akun $@$ kecamatan.cinambo. Adapun biodata dalam akun @ kecamatan.cinambo hanya berupa keterangan nama KecCinambo, penggunaan \#BandungNuUrang209 yang merupakan kampanye pengenalan Kecamatan Cinambo, alamat akun media sosial lainnya seperti Twitter, Facebook, Youtube, serta alamat e-mail maupun website Kecaamatan Cinambo. Selanjutnya, PEDASI dan staf IT juga menerapkan keahlian teknis dalam memanfaatkan fitur pada Instagram sebagai media informasi kecamatan. Adapun fitur-fitur Instagram @ kecamatan.cinambo yang sering digunakan adalah unggah foto, pemberian caption atau tulisan, pemberian mention atau penyebutan. Kesemua fitur tersebut digunakan sebagai pembaharuan galeri atau feeds Instagram @kecamatan.cinambo. Secara teknis PEDASI dan staf IT sudah memiliki keahlian untuk melakukan pembaharuan setiap harinya, maka dari itu Kecamatan Cinambo sebagai salah satu kecamatan yang aktif dalam berkegiatan.

\footnotetext{
${ }^{5}$ Wawancara Faisal, staf Seksi Keterbukaan Informasi Publik Diskominfo, Agustus 2019, Diskominfo Kota Bandung.
}

Selain mengunggah pada feeds, PEDASI maupun staf IT memanfaatkan fitur Insta Stories dan sorotan sebagai menu yang dapat melaporkan atau mempublikasikan giat Camat dan jajarannya secara langsung dengan format video. Hal ini dilakukan bagi kegiatan yang dihadiri orang-orang penting di tingkat Kota Bandung sebagai pelaporan yang segera. Tidak hanya itu, bagi pengikut Instagram @kecamatan.cinambo dapat menjadi informasi yang update dan realtime pada saat kegiatan berlangsung. Keahlian teknis lain adalah PEDASI maupun staf IT harus memiliki keahlian dalam menggunakan software multimedia baik untuk penyuntingan gambar, desain grafis, dan video. Adapun software tersebut yakni Corel Draw, Photoshop, Adobe Premier, Quick dan Prodirector. Keempat software tersebut tidak digunakan dalam setiap unggahan pada Instagram, namun dikhususkan untuk pelaporan acara-acara tertentu yang memang menjadi acara besar kecamatan. Namun untuk unggahan setiap harinya, PEDASI maupun staf IT hanya memanfaatkan fitur yang ada di Instagram seperti filter, brightness, dan grid untuk menyajikan beberapa jumlah gambar dalam satu unggahan.

Kemampuan lain yang harus dimiliki untuk mendukung penggunaan media Instagram adalah keterampilan pengolahan kata agar menghasilkan konten yang informati serta edukatif. PEDASI dan staf IT wajib memiliki keterampilan dalam mengemas pesan atau caption di setiap unggahan gambar di Instagram. Hal terpenting dari kemampuan pengolahan kata adalah pembuatan kalimat yang menarik dan mengandung unsur kepantasan, sifatnya informatif, edukatif dan persuasif. Seperti yang dikatakan operator @ kecamatan.cinambo yakni, "Yang pertama diajarin buat bikin kalimat yang bisa bikin orang penasaran gitu, pengen lihat gitu"6. Oleh karena itu, dalam membuat tulisan pada caption Instagram, PEDASI melakukan proses seleksi pesan yang telah dibuat staf IT dengan kriteria harus memuat $4 \mathrm{~W}+1 \mathrm{H}$ (What, Where, When, Who, dan How). Kriteria tersebut merupakan suatu keharusan yang disajikan oleh staf IT selaku tim peliput giat Kecamatan

\footnotetext{
${ }^{6}$ Wawancara Informan Rizal Operator Instagram @kecamatan.cinambo, Juni 2019, Kecamatan Cinambo, Kota Bandung
} 
Cinambo. Penjelasan What yakni staf IT sebelum mengunggah gambar harus mencantumkan nama kegiatan yang sedang dilakukan. Kriteria Where, staf IT harus mencantumkan tempat kegiatan berlangsung. Kriteria When, staf IT harus mencantumkan waktu (hari) dan tanggal kegiatan berlangsung. Kriteria Who, staf IT harus mencantumkan siapa saja yang terlibat dalam kegiatan tersebut. Selain itu, staf IT harus menggunakan fitur mention sebagai penyebutan pihak yang terlibat maupun pelaporan kinerja kecamatan bagi Pemerintah Kota Bandung, Wali Kota, dan Sekretariat Daerah. Untuk kriteria How, dijelaskan melalui penggambaran foto atau gambar yang diunggah, bagian ini harus menampilkan pimpinan Camat, pihak yang terlibat dalam kegiatan, dan interaksi peserta kegiatan.

Keahlian tersebut menjadikan PEDASI maupun staf IT harus memiliki keahlian teknis di bidang dokumentasi kegiatan baik gambar ataupun video. Diakui PEDASI, keahlian teknis untuk dokumentasi adalah penguasaan pengambilan gambar berdasarkan momen penting dengan mempertimbangkan sudut pengambilan yang mengandung nilai informasi ataupun berita. Hal ini dilakukan agar menarik followers yang notaben warga Cinambo. Keseluruh keahlian teknis yang dimiliki PEDASI dan staf IT berdasarkan pengalaman pembelajaran pribadi. PEDASI hanya diberikan garis besar instruksi Camat yang selanjutnya dikembangkan berdasarkan keahlian dan pengetahuan yang dimiliki secara pribadi. Hal ini diakui oleh Camat Cinambo terkait kemampuan tersebut para operator maupun PEDASI sudah mahir dan memahami apa yang menjadi tugasnya. Camat Cinambo cukup memberikan instruksi serta arahan terkait hal apa yang harus dipublikasikan, selebihnya para operator dan PEDASI yang memiliki kreativitas untuk mengemas pesan tersebut.

"...Tinggal bagaimana dorongan kita aja, seperti: ini tampilkan, tampilkan ini jangan lupa nah gitu kan. Mengingatkan tapi kalau seksi operasionalnya, teknisnya, operatornya itu bagian IT. Dan itu bagian informasi saja. Kalau saya disini, menginformasikan saja bahwa kita

${ }^{7}$ Wawancara Informan Camat Cinambo, Juni 2019, Kecamatan Cinambo, Kota Bandung itu bekerja, kita itu beraktivitas supaya masyarakat tahu, pimpinan juga disana tahu, dimana-mana juga tahu jika di Cinambo itu aparaturnya ternyata berkarya, berkinerja, terutama kalau sudah berkegiatan bersamasama". 7

Kemampuan pengemasan pesan tersebut menjadi perhatian pula oleh DISKOMINFO Kota Bandung, terutama untuk menjawab komentar dan Direct Message yang masuk dari masyarakat. Hal ini dikarenakan terdapat beberapa permasalahan operator Instagram dalam memberikan respon yang tidak terprovokasi oleh pengaduan masyarakat. Oleh karena itu DISKOMINFO Kota Bandung dan Humas Pemerintah Kota Bandung senantiasa memberikan pelatihan untuk penggunaan media sosial sebagai media informasi dan interaksi warga melalui bimbingan teknis. Hal tersebut disepakati oleh Faisal, staf dari DISKOMINFO Kota Bandung, "Maksudnya kikuk itu gini kan dari berbagai macam masyarakat, berbagai macam Bahasa. Bahasanya ada yang provokatif, ada yang biasa aja begitu. Nah yang berprovokatif ini kebanyakan adminnya tuh ikut emosi jadi balesnya juga jadi asa aing weh emosi siga nu ngajak gelut yeuh dilawannya teh jadi gitu. Nah itu mengajarkan itu yang susah makanya waktu itu ada pelatihan untuk menjawab caption lewat DM, ada komen di bawah caption-nya karena itu masyarakat kan mungkin saja ada yang memancing setelah kepancing capture tampilin dan di share di FB nya mungkin"8.

Penerapan keahlian teknis media sosial Instagram pada PEDASI ini harus bermula dari keahlian dalam mengakses akun media sosial dan selanjutnya menggunakan media sosial sebagai media informasi kecamatan. Konsep Use (Menggunakan), merupakan keahlian teknis yang dibutuhkan untuk terlibat dengan komputer dan internet. Keahlian ini membentuk dasar untuk pengembangan literasi digital yang lebih dalam. Keterampilan teknis yang penting meliputi kemampuan untuk menggunakan program

8 Wawancara Informan Faisal, staff DISKOMINFO, Agustus 2019, Kota Bandung 
komputer seperti pengolah kata, web browser, email, dan alat komunikasi lainnya ${ }^{9}$. Pengembangan literasi digital terlihat pada pemanfaatan Instagram @kecamatan.cinambo yang digunakan sebagai media pelaporan kinerja atau kegiatan kecamatan secara cepat, aktual, dan faktual. Aktivitas Instagram @kecamatan.cinambo sebagai media pelaporan kegiatan dan kinerja Kecamatan Cinambo kepada pimpinan Pemerintah Kota Bandung secara real time. Penyebaran informasi atau berita tersebut biasanya dapat dikombinasikan dengan video, foto, audio, dan teks, yang kemudian secara langsung diunggah pada media sosial Instagram tidak lama dari saat kejadian. Seperti yang dijelaskan oleh Camat Cinambo, adanya Instagram dapat melengkapi bukti kegiatan atau bukti kinerja yang dilakukan Kecamatan Cinambo setiap harinya. Bukti kinerja ini menjadi dasar penilaian keaktifan menjalankan program pemerintah kota, hal ini terintegrasi dengan Sistem Informasi Pemerintahan (SIP).

"Setiap kita (pimpinan kecamatan) katakanlah beraktivitas dan nanti ada instrumennya SIP maka kita upload yang dari IG.... Semakin banyak terisi item ini, maka semakin bernilai baik kinerja seorang pemimpin di wilayah itu... salah satunya tadi bukti kita kinerja secara tanggung jawab kedinasan. Yang kedua masuk juga ke format penilaian kinerja kita oleh pimpinan. sudah itu pasti bagian yang saling mendukung kan" 10 .

Aktivasi distribusi informasi pada Instagram @kecamatan.cinambo sebagai fungsi tambahan sebagai media pelengkap pelaporan kinerja kecamatan, karena terdapat empat indikator kerja utama kecamatan. Indikator tersebut yakni kualitas layanan publik, aktivitas media sosial, rekap layanan tepat waktu, dan penyelenggaraan tugas kinerja. Baik aktivitas media sosial dan penyelenggaraan tugas kinerja harus terlaporkan setiap hari kerja secara langsung, sehingga antara aktivitas media sosial dengan tugas harian

\footnotetext{
${ }^{9}$ Media Networking Awarness. National Broadband Plan Connecting Maerican Section 9.3, Digital Britain Media Literacy Working Group Section 3.16, dan Australia's Digital Economy: Future Directions., 2011
}

kecamatan, terutama pimpinan sangat berkaitan untuk penilaian kinerja.

\subsection{Penerapan Aspek Pemahaman Kritis Pada PEDASI Kecamatan Cinambo}

Aspek pemahaman kritis pada PEDASI

Kecamatan Cinambo terlihat adanya penerapan pemahaman tugas dan tanggung jawab PEDASI serta mengevaluasi konten dapat dipahami followers ataupun warga Cinambo. PEDASI sebagai petugas pengolah data dan sistem informasi Kecamatan Cinambo sudah memahami tugas dan tanggung jawab untuk mengelola konten yang akan dipublikasi pada Instagram @kecamatan.cinambo. Secara kontekstual PEDASI akan mempublikasikan setiap kegiatan kecamatan yang termasuk dalam program kerja, kemudian dibuatkan posting foto, tulisan, ataupun video sebagai pelaporan kegiatan kecamatan kepada pimpinan Kota Bandung ${ }^{11}$. PEDASI selain memahami tugas dan konteksualitas konten yang dipublikasikan, PEDASI juga melakukan evaluasi media digital secara kritis. Evaluasi kritis yang dilakukan PEDASI adalah memastikan setiap konten yang disajikan mencerminkan kegiatan Camat Cinambo. Hal ini terlihat dari setiap konten yang dipublikasikan selalu memperlihatkan pimpinan Kecamatan Cinambo sedang melaksanakan kegiatannya yang diantaranya berupa menghadiri apel rutin, rapat paripurna bersama Pemerintah Kota Bandung, shalat subuh dan shalat jumat keliling, makan bersama warga Cinambo, kegiatan kepedulian kepada warga, pelantikan dan pembukaan acara di tingkat kelurahan dan penerimaan kunjungan kerja dari berbagai institusi. Selain menampilkan sosok pimpinan Camat Cinambo, dalam konten yang dibuat juga menampilkan peran serta jajaran ASN Kecamatan Cinambo aktif berkegiatan, seperti senam rutin, gerakan kebersihan, pengajian bersama warga, dan kegiatan lain yang melibatkan warga.

Berdasarkan pencerminan tersebut, secara kritis menimbulkan persepsi followers yang diantaranya warga Cinambo dan SKPD Kota

\footnotetext{
${ }^{10}$ Wawancara Camat Cinambo, Juni 2019, Kecamatan Cinambo

${ }^{11}$ Wawancara Informan Igman Operator Instagram @kecamatan.cinambo, Juni 2019, Kecamatan Cinambo, Kota Bandung
} 
Bandung, menilai Kecamatan Cinambo sebagai kecamatan aktif berkegiatan. Persepsi lain juga yang terbangun diantara warga Cinambo dengan banyaknya posting konten melalui penekanan sosok pimpinan Camat Cinambo selalu dekat dengan warganya. Hal ini terlihat dari beberapa konten yang dipublikasikan mendapat love dan komen positif dari followers. Selain itu, tidak sedikit warga Cinambo yang melakukan tagging atau menandai @ kecamatan.cinambo pada beberapa konten yang warga buat ketika menarik untuk disajikan ataupun sebagai bahan pelaporan warga terkait masalah di sekitar Cinambo. Baik secara dunia maya atau virtual PEDASI Kecamatan Cinambo mampu membentuk kesan positif kecamatan sesuai dengan fakta di lapangan atau keseharian kegiatan pimpinan Camat beserta jajarannya.

Terbangunnya pemahaman kritis bagi PEDASI Kecamatan Cinambo ini tidak terlepas dari pengembangan keterampilan manajemen informasi. Keterampilan manajemen informasi PEDASI Kecamatan Cinambo meliputi, pencarian data (konten) atau pengumpulan data (konten), penyusunan data (konten), mengklasifikasikan data (konten), dan penyajian data (konten) di media sosial. Proses manajemen informasi terkait pembuatan konten menurut salah satu staf IT sudah berjalan sesuai arahan pimpinan kecamatan. Dijelaskan lebih lanjut oleh PEDASI proses dalam melakukan manajemen informasi dengan menghimpun arahan pimpinan terkait agenda kegiatan apa saja yang akan dilakukan oleh pimpinan kecamatan maupun jajarannya. Agenda kegiatan ini akan dibuat setiap harinya dan disebarkan melalui Whatsapp Group aparatur Kecamatan Cinambo ${ }^{12}$. Setelah agenda ini dipublikasikan kepada staf IT maupun PEDASI, selanjutnya dalam proses pencarian konten, para staf IT maupun PEDASI membagi tugas untuk mendampingi pimpinan atau meliput jalannya kegiatan ${ }^{13}$. Setelah peliputan selesai, staf IT maupun PEDASI melanjutkan proses penyusunan pesan untuk dibuat menjadi sebuah konten pada Instagram $@$ kecamtan.cinambo. Penyusunan ini dilihat dari banyaknya kegiatan yang diagendakan dan diliput

\footnotetext{
${ }^{12}$ Prosiding Democracy and Public Accountability In Digital Era, 2019, FHISIP Universitas Terbuka ${ }^{13}$ Ibid $^{12}$
}

para operator IT. Penyusunan juga didasarkan dari indikator kinerja kecamataan yang akan dilaporkan serta berhubungan dengan warga Kecamatan Cinambo. Hal ini diungkapkan oleh Satf IT sekaligus PEDASI Kecamatan Cinambo, "Jadi tidak dibatasi pokoknya selama kegiatan yah? Iyah dan kegiatannya mungkin berhubungan dengan warga. Terus ke indikator yang tadi nyambung ke indicator yang tadi pasti kita laporkan" 14 .

Proses selanjutnya dari manajemen informasi PEDASI adalah mengklasifikasikan data untuk pembuatan konten. Klasifikasi yang dilakukan yakni pemisahan foto atau video kegiatan berdasarkan urutan utama atau momen penting. Untuk menghasilkan konten bernilai berita, foto atau video yang digunakan dimulai dari adanya pembukaan, inti dan peserta kegiatan. Klasifikasi pembukaan memperhatikan penonjolan tokoh sentral, seperti Pimpinan Kecamatan Cinambo. Pembukaan ini ditandai dengan adanya urutan pertama dalam sebuah susunan foto-foto kegiatan yang akan dipublikasi. Klasifikasi inti kegiatan yang dilakukan dengan penonjolan angle atau sudut pandang orang-orang yang terlibat pada kegiatan tersebut. Hal ini ditandai dengan foto yang digunakan menggambarkan suasana saat kegiatan berlangsung serta interaksi yang terjadi antara tokoh sentral dengan peserta kegiatan. Terakhir, klasifikasi penutup terdiri dari foto yang disajikan menggambarkan antusiasme peserta kegiatan. Proses klasifikasi ini termasuk juga dalam proses penyeleksian gambar yang digunakan maupun pesan atau captions yang akan disampaikan ${ }^{15}$.

Proses manajemen informasi terkait penyajian data atau konten dilakukan para operator IT setelah melewati hasil penyeleksian gambar dan pesan yang sudah dibuat melalui pengisian captions. Konten yang tersaji di Instagram @ kecamatan.cinambo tidak ada standar baku selama konten tersebut informatif dan dapat menjadi bahan laporan kinerja kepada pimpinan Kota Bandung, maupun instansi terkait. Penyajian data melalui Instagram @ kecamatan.cinambo tidak hanya memanfaatkan fungsi kronologi (feeds) sebagai tempat publikasi konten berupa gambar

\footnotetext{
${ }^{14}$ Wawancara Andri Staf IT Kecamatan Cinambo, Juni 2019, Kecamatan Cinambo, Kota Bandung ${ }^{15} \mathrm{Ibid}^{12}$
} 
kegiatan, video kegiatan, poster kegiatan atau infografis informasi positif (klarifikasi fakta) yang sedang trend, dan ucapan peringatan maupun ucapan selamat kepada instansi lain yang terkait dengan wilayah Cinambo. Untuk menyajikan konten yang faktual dan terkini, staf IT maupun PEDASI Kecamatan Cinambo memanfaatkan fungsi stories (cerita) untuk membuat video secara langsung (live video) saat kegiatan berlangsung ${ }^{16}$. Berdasarkan proses manajemen informasi, PEDASI memberikan pemecahan masalah kepada warga Cinambo yang membutuhkan informasi seputar kecamatan. Selain itu, Instagram @kecamatan.cinambo menjadi media pelaporan warga, ketika terjadi permasalahan di sekitar wilayah Cinambo dengan fitur Direct Message ataupun Komen pada setiap konten. Konten Instagram @kecamatan.cinambo dijadikan sarana pemecahan masalah untuk data base lampiran dokumentasi kegiatan kecamatan untuk pelaporan kinerja kepada Pemerintah Kota Bandung.

\subsection{Penerapan Aspek Produksi Konten Pada PEDASI Kecamatan Cinambo}

Aspek produksi konten pada PEDASI Kecamatan Cinambo terkait dengan keterampilan PEDASI dan staf IT membuat konten informasi kegiatan kecamatan. Keterampilan ini melibatkan keterampilan teknis dan kemampuan pengolahan kata, gambar, dan video. Keterampilan teknis meliputi keahlian dalam mengakses aplikasi Instagram dan memproduksi konten dalam fitur feeds ataupun stories. Pada keterampilan teknis, PEDASI maupun staf IT saat peliputan langsung memproduksi konten gambar kegiatan melalui smartphone yang dimiliki masing-masing individu. Pada proses pengambilan gambar kegiatan PEDASI maupun staf IT mempertimbangkan aturan estetika pengambilan gambar. Estetika tersebut yakni dalam sebuah gambar dapat memberi pesan informatif serta menarik warga yang melihat kegiatan tersebut di Instagram @ kecamatan.cinambo. PEDASI maupun staf IT biasanya mengambil gambar dengan angle eye level, posisi dan arah kamera memandang objek yang akan dipotret sejajar dengan tinggi objek. Maksud pengambilan gambar dengan angle

${ }^{16} \mathrm{Ibid}^{12}$ ini, diharapkan hasil gambar memuat informasi aktivitas kegiatan kecamatan.

Proses pengambilan gambarpun tidak hanya satu kali, namun dilakukan beberapa kali untuk disimpan dalam stock shoot. Stock shoot ini difungsikan sebagai cadangan proses seleksi pemilihan gambar yang akan ditampilkan pada akun Instagram @ kecamatan.cinambo. Gambar-gambar yang sudah dikumpulkan biasanya oleh staf IT dikirimkan kepada PEDASI untuk dilakukan proses seleksi. Proses seleksi melihat dari beberapa stok gambar yang harus mengambil posisi depan, kanan dan kiri. Selain itu dalam foto juga harus memperlihatkan peserta kegiatan. Setelah dilakukan proses seleksi gambar, selanjutnya dikembalikan kepada staf IT untuk dibuatkan grid untuk membatasi jumlah gambar yang akan ditampilkan. Proses grid yang dimaksud adalah membuat pilihan beberapa gambar dalam satu unggahan feeds Instagram@kecamatan.cinambo.

Proses selanjutnya adalah keterampilan dalam pengolahan kata, PEDASI maupun staf IT sebelum mempublikasi gambar yang sudah disunting harus memberikan tulisan penjelas atau captions. Secara aturan atau standar internal untuk penulisan captions harus terdiri dari nama kegiatan, tempat kegiatan, waktu kegiatan, pihak yang terlibat, dan menyebutkan akun instagram Wali Kota Bandung, Pemerintah Kota Bandung, dan Humas Pemerintah Kota Bandung. Bagi kegiatan lain di luar dari kegiatan rutin Kecamatan Cinambo, biasanya operator IT menyebutkan akun instagram pihak yang terlibat, seperti dinas, instansi, maupun kelompok masyarakat. Penyebutan tersebut dimaksud sebagai bukti pelaporan kegiatan kepada pimpinan kota, sedangkan bagi dinas, instansi, maupun kelompok masyarakat diperuntukkan sebagai arsip kegiatan yang sudah dilaksanakan ${ }^{17}$.

Dalam akun Instagram

@ kecamatan.cinambo memang lebih fokus kepada penyajian produksi gambar dan caption penjelas gambar ketimbang video. Hal ini dikarenakan produksi video harus menjalani proses penyuntingan yang cukup memakan banyak waktu. Penyajian video hanya diperuntukan pada momenmomen tertentu, seperti momen penting kedatangan Wali Kota Bandung, Ibu Wali Kota Bandung,

${ }^{17}$ Ibid $^{12}$ 
Pejabat Daerah, dan kegiatan besar kecamatan yakni kompetisi ataupun pelaksanaan program kerja Kota Bandung. Sedangkan untuk video yang sifatnya terkini dan faktual, PEDASI maupun staf IT memanfaatkan fitur Insta Stories untuk mendokumentasikan bagian-bagian penting dari kegiatan tersebut. Pada stories tersebut, penyajian kata yang dibuat hanya penyebutan akun instagram Wali Kota Bandung, Pemerintah Kota Bandung, dan Humas Pemerintah Kota

Bandung dan instansi yang terlibat di kegiatan tersebut. Selain itu, PEDASI juga menambahkan lokasi saat kegiatan berlangsung.

Aspek keterampilan produksi konten pada PEDASI sangat diperlukan untuk membangun komunikasi yang aktif antara pihak kecamatan dengan followers. Komunikasi yang aktif berupa adanya umpan balik yang diberikan followers dalam bentuk "like" atau "comment" dalam setiap gambar yang dipublikasikan.

\subsection{Model Penerapan Literasi Media Sosial Instagram Pada PEDASI Kecamatan Cinambo}

Berdasarkan penjelasan mengenai penerapan tiga aspek literasi media sosial Instagram pada PEDASI Kecamatan Cinambo dapat menghasilkan model penerapan yang terdiri dari keahlian teknis, pemahaman kritis, dan produksi konten. Model ini saling berkaitan dalam setiap aspeknya, sehingga literasi media sosial akan menggambarkan kemampuan seorang operator yang meliputi tiga bagian. Adapun model penerapan literasi media sosial Instagram @ kecamatan.cinambo yang terjadi pada PEDASI Kecamatan Cinambo sebagai berikut,

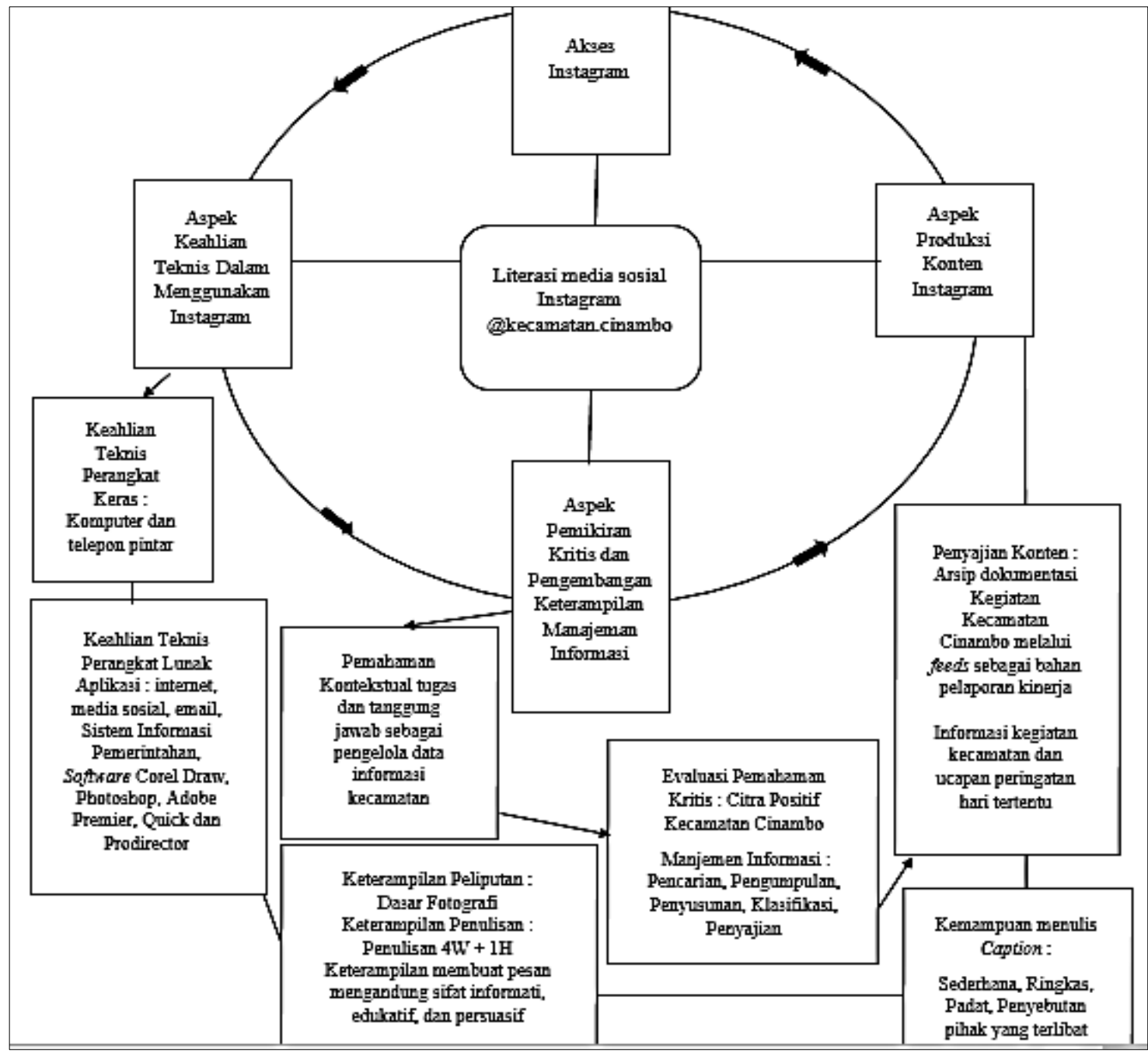

ArtComm - Jurnal Komunikasi dan Desain 
Sumber: Olah Data Penulis, 2019

\section{Gambar 4.1 Model Penerapan Literasi Media Sosial Pada PEDASI Kecamatan Cinambo}

\section{KESIMPULAN}

\subsection{Kesimpulan}

Adapun kesimpulan dari penelitian ini adalah, 1. Penerapan Keahlian Teknis PEDASI Kecamatan Cinambo meliputi keahlian mengakses media sosial khususnya Instagram, keahlian teknis dalam menggunakan perangkat komputer, laptop, dan smartphone. Selain itu PEDASI memiliki keahlian teknis dalam menggunakan aplikasi atau fitur dalam Instagram dan software penyuntingan gambar dan video. Keahlian yang penting dari seorang PEDASI secara teknis yakni keahlian dalam mengolah kata, gambar, dan video agar mengandung pesan yang informatif, edukatif, dan persuasif.

\subsection{Saran}

Adapun saran dalam penelitian ini adalah sebagai berikut,

1. Diharapkan model penerapan ini tidak hanya diterapkan di Kecamatan Cinambo, namun juga dapat diterapkan pada beberapa kecamatan di Kota Bandung yang kurang aktif dalam bersosial media.

2. Literasi media sosial di lingkungan Kecamatan Cinambo dapat berkembang dengan

\section{REFERENSI}

Atmoko Dwi, B. 2012. Instagram Handbook Tips Fotografi Ponsel. Jakarta: Media Kita.

Chen, D.-T., Wu, J., \& Wang,Y. 2011.

Unpacking New Media Literacy. Journal on Systemics, Cybernetics and Informatics. P.84-88

Flew, T. 2008. New Media : an Introduction. New York: Oxford University. Martin, A. 2009. Digital Literacy for the Thrid Age: Sustaining Identity in an Uncertain World. e-learningpapers.eu.
2. Penerapan Pemahaman Kritis PEDASI Kecamatan Cinambo meliputi pemahaman tentang tugas yang diberikan, kontekstualitas tugas pengolah data dan penyedia informasi kegiatan kecamatan, dan evaluasi dalam membentuk citra positif Kecamatan Cinambo melalui manajemen informasi pada akun Instagram@kecamatan.cinambo.

3. Penerapan Aspek Produksi Konten Pada PEDASI Kecamatan Cinambo meliputi penyajian konten kegiatan Kecamatan Cinambo berdasarkan agenda kegiatan mingguan, ucapan peringatan yang dikemas melalui pengolahan gambar dan video yang menekankan pada penonjoloan Pimpinan Kecamatan Cinambo, serta tulisan penjelasan melalui caption secara sederhana, ringkas, padat, dengan menyebutkan pihakpihak terkait dalam kegiatan tersebut.

dukungan infrastruktur free wi-fi atau hotspot bagi warga Cinambo sehingga warga dapat memanfaatkan jaringan tersebut untuk mengakses Instagram @kecamatan.cinambo.

3. Perlu pengembangan manfaat fitur instagram oleh pihak PEDASI dan pengembangan pengolahan berita yang lebih rinci, agar menarik followers dalam mendapatkan informasi yang bernilai berita.

McQuail, D. 2011. Teori Komunikasi Massa

McQuail. Jakarta: Salemba.

Media Networking Awarness. National

Broadband Plan Connecting Maerican

Section 9.3, Digital Britain Media Literacy

Working Group Section 3.16, dan

Australia's Digital Economy: Future

Directions. (2011). p. 44.

Sulianta, Feri. 2015. Rahasia Berbisnis Ala

Sosial Media. Yogjakarta : Andi.

Sugiyono. 2007. Metode Penelitian Kuantitatif, Kualitatif, dan R\&D. Bandung : CV. Alfabeta. 
Windyaningrum, Rachmawati, dkk

https://ppid.kominfo.go.id/standar-layanan-ip/, 2019.Prosiding Democracy and Public Accountability In Digital Era, FHISIP diakses pada tanggal 12 Agustus 2019 pukul Universitas Terbuka 11.20

\section{Referensi Lain}

